\title{
Vaccination Situation in the First Month of Life of Children of Childhood Education
}

\begin{abstract}
Luiza Helena dos Santos Wesp', Paula Fernanda Brandão Batista dos Santos², Willyana Freire Bispo1, Mariana Fernandes de Almeida Silva ${ }^{3}$, Lidiana Luana Inácio da Silva ${ }^{1}$, Talita de Figueiredo Galhardo ${ }^{4}$, Michelle da Silva Carneiro Galvão ${ }^{5}$, Eliabe Rodrigues de Medeiros ${ }^{6}$, Erika Simone Galvão Pinto ${ }^{7}$
\end{abstract}

\section{Abstract}

Introduction: The Brazilian vaccination schedule is a strategy used in disease prevention by providing immunobiologicals to the population and the BCG and Hepatitis B vaccines are the first to be administered shortly after birth.

Objective: Describe the vaccination status of BCG and Hepatitis B vaccines in the first month of life of children of childhood education.

Method: Epidemiological, descriptive and retrospective study, with quantitative approach, conducted from data available in 1,434 copies of children's immunization cards enrolled in childhood education in the municipality of Natal/RN, Brazil. Data were collected through checklist, categorized by Microsoft Office Excel 2013, exported to statistical software and presented in tables and graphs through simple descriptive statistics.

Results: The BCG vaccine showed $98.5 \%$ of children with full immunization schedule, $1.2 \%$ unvaccinated and $0.8 \%$ had record failures. In the case of the hepatitis B vaccine, $98.9 \%$ had complete vaccination schedule, $0.6 \%$ for unvaccinated children and $0.4 \%$ had flaws that prevented their analysis.

Conclusions: The vaccination status of the children had complete immunization schedule rates higher than the target set by the National Immunization Program, but the presence of registry errors prevented the analysis of cards.
1 Nurse. Specialization Student in Neonatal and Pediatric Intensive Care Unit of the Metropolitan College of Sciences and Technology (FAMEC), *

2 Nurse. PhD in Social Sciences. Professor at the Federal University of Rio Grande do Norte (UFRN), *

3 Graduation Student in Nursing at the Federal University of Rio Grande do Norte (UFRN), *

4 Nurse. Specialist in Occupational Nursing of the Integrated Faculties of Patos (FIP), *.

5 Nurse. Specialist Health and Specialization Student in Nursing in Dermatology and Wound Treatment at the University Potiguar (UnP), *.

6 Nurse. MSc Student in Nursing at the Federal University of Rio Grande do Norte (UFRN), *

7 Nurse. PhD in Nursing. Professor at the Federal University of Rio Grande Norte (UFRN), *.

*: Natal/RN, Brazil.

\section{Contact information:}

\section{Paula Fernanda Brandão Batista dos Santos.}

Address: Federal University of Rio Grande do Norte, Health Sciences Center, Department of Nursing. BR 101, s/n, Lagoa Nova, CEP: 59072-970. Natal, RN, Brazil.

झ paulafernandabb@hotmail.com

\section{Keywords}

Pediatric Nursing; Vaccines; Vaccinations Against Hepatitis B; BCG Vaccine. 


\section{Introduction}

The vaccine is an important strategy for protection against infectious diseases, with individual and collective contributions to reduce the spread of diseases. That statement is strengthened when based on data from the World Health Organization (WHO) and the UN Children's Fund (UNICEF), indicating that 2.5 million children under five years of age die annually in the world by diseases that could be prevented by immunization measures [1, 2].

Considering the importance of providing immunobiological to the population, Brazil has, since 1973, the National Immunization Program (NIP), public health policy implemented in Primary Health by the Unified Health System (SUS), by offering the immunobiologicals that make up the immunization schedule. Since 2004, with the publication of the Ministerial Decree MS/GM No. 597/2004, the calendar was divided by life cycles and arranged in the calendars of children, adolescents, women of childbearing age, adults and elderly, demonstrating greater control and monitoring of the epidemiological behavior of infectious agents, along its trajectory in Brazilian society [3, 4].

The first basic vaccination schedule for children under one year of age was instituted in 1977 [5], and every year it is reviewed and updated in order to foster expansion in preventing immunopreventable diseases and seek fewer side effects, greater immunogenic power and a better cost-effective. The Brazilian calendar of current child vaccination has 11 vaccines, aimed at protection for about 15 infectious agents [6].

Thus, the importance and benefits of a complete immunization schedule for children in their first five years of life are unquestionable, as they have an immature immune system that leaves them susceptible to infections.

According to the immunization schedule of the child, at birth, the child should receive one dose of the vaccine against Bacille Biliard Calmette-Guérin (BCG) and one dose for Hepatitis B. Preferably, this administration must occur within the first 12 hours of life.

The first use of the BCG vaccine in humans was in 1921, and the immunization schedule of the child was implemented in 1977, along with other vaccines such as polio, measles, diphtheria, tetanus and pertussis. BCG is indicated to prevent severe forms of tuberculosis (miliary and meningeal). Its scheme consists of a single dose at birth, $0.1 \mathrm{ml}$ administered intradermally, and may be administered up to the age of four years, 11 months and 29 days. The recommendation is a booster dose at the age of six years. This work focused on the first dose, which should be given at birth [6].

The Hepatitis B vaccine contains the recombinant surface antigen ( $\mathrm{HBsAg}$ ), preventing the infection by the hepatitis $B$ virus, being introduced in the child's immunization schedule in 1986. Currently, its corresponding administration schedule is three doses, in which newborns should receive the first dose (monovalent) preferably in the first 12 hours of life, up to 30 days of life. The continuity of the vaccination schedule is made with the adsorbed pentavalent vaccine, consisting of the antigens of diphtheria, tetanus, pertussis, Hepatitis B (recombinant) and Haemophilus influenzae b (conjugate) being given in the second, fourth and sixth months of life.

The first vaccines administered to children shortly after birth consist of those two immunobiological. According to the Ministry of Health, the expectation of vaccination coverage of children under one year for those vaccines is $95 \%$. In this sense, the objective of this study is to describe the vaccination status of children under one year enrolled in the Municipal Centers of Childhood Education (CMEI) for vaccines of the first month of life, BCG and Hepatitis B.

\section{Methods}

This study refers to an epidemiological, descriptive and retrospective survey, with quantitative approach. As an epidemiological study, it is an impor- 
tant tool for diagnosis of the population's health situation, since it generates quantitative data on the health of the entire child population of Municipal Centers of Childhood Education of northern Natal. In this sense, the descriptive study allows organizing such data, presented in frequency in order to highlight the health situation studied in that population [7].

The Ministry of Health of Brazil bases on the immunization coverage to estimate the amount of the target population that received the vaccine with correct age and range, and, thus, to estimate the extent of vaccination actions in the municipalities, regions and the country. The vaccination coverage indicator consists of the number of applied doses (corresponding to the full vaccination scheme) of certain immunobiological divided by the target population and multiplied by 100 , in certain considered area and time. This indicator expresses the percentage of people vaccinated and potentially protected against certain disease [8, 9].

That indicator allows estimating how many people in the country are "protected" and how many are susceptible; such information tends to contribute to the quality of care provided by health services, serving for organization and planning of actions aimed at full coverage and, thus, the prevention and protection of the population [10].

On the other hand, studies performed on vaccination coverage have pointed out that the data reported by the information system often generate overestimation or underestimation of the actual vaccination coverage of children under one year. One of the problems associated with those differences relate to the actual calculation of the indicator, which would relate to under or oversizing of the denominator by errors in population estimates of the target population in intercensal years. Another factor that may have implications refers to birth records that, in some parts of the country, are incomplete and do not reflect the real birth rate. Those results can lead to errors in the estimation of vaccination coverage, with values above 100\% [11].
In this sense, and to avoid confusion with the concepts, one used the term "vaccination status" to describe the vaccination status of children here studied. Therefore, there was no estimation of the coverage, but one sought to describe the vaccination status evidenced through vaccination cards.

This study based on secondary data available in the documents concerning the enrollment of children, specifically in copies of vaccination cards required as a condition for effective enrollment in schools. The amount of children in CMEls in northern Natal was 4,387 children enrolled in 2015. Nevertheless, when applying the criteria of inclusion and exclusion from the study, we obtained 1,434 vaccination cards for analysis and classification. The inclusion criterion was being a child enrolled in CMEl in northern Natal; the exclusion criterion was not having, at the time of the data collection, an updated copy of vaccination card.

The data collection procedure took place between March and December 2015, and used, as a data collection instrument, a checklist based on the immunization schedule recommended by the NIP for administration of BCG and Hepatitis B vaccines.

Vaccine cards were classified into two groups: full or updated vaccination schedule, when the child received the vaccine dose, regardless of the period, and not vaccinated, when there was no dose registration of the vaccine in the vaccination card. However, according to the used checklist, it was possible to make an analysis considering the period in which the child took the vaccine, if the administration was within the period recommended by the Ministry of Health, that is, the first 15 days of life.

Data were tabulated in Microsoft Office Excel 2013 program, analyzed based on simple descriptive statistics and presented in tables with absolute value and simple percentage, considering the crossing of the variables age and type of vaccine.

The study followed the ethical principles of the Resolution 466/2012 of the National Health Council (CNS), requiring the signature of the Informed Consent Form by the child's guardian and approved by 
the Ethics Committee of the Federal University of Rio Grande North under Opinion No. 835,410 and CAAE No. 32516914.4.0000.5537.

\section{Results}

There was visitation to 26 of the 27 existing CMEls, located in the northern Natal/RN. One CMEl did not join the research because its activities had not initiated at the time of the data collection. Of the 4,387 enrolled children, 1,434 vaccine cards composed the sample. Those institutions attend children aged six months to six years, in the following classes: nursery I and II, Level I, Level II, Level III and Level IV. For better understanding and analysis, there was division of the data considering the age group: children between six months and one incomplete year; between one year and two years old; between two years and three years old; and so on, as presented in graphs and tables.

Among the 1,434 analyzed cards, seven belonged to children between six months and one incomplete year; 54, to children between one and two incomplete years; 180, to children from two to three incomplete years; 300 cards, to children from three to four incomplete years; 378, to children between four and five incomplete years; 382 cards, to children between five and six incomplete years; and other 133, to children from six to seven incomplete years.

Table 1 shows data on the vaccination status of children in relation to the BCG vaccine. According to the table, the classification of $98.5 \%$ of the cards, considering all age groups, was full vaccination scheme for the BCG single dose. For unvaccinated, there was $1.2 \%$ of the cards. As for the registration failure, there was only $0.8 \%$, in the age group from five to six years. Those registry failures refer to illegible notes, such as date and name of the vaccine, which prevented classification.

According to data collected from the checklist, it was possible to classify those cards regarding the administration period of the vaccines. (Figure 1)

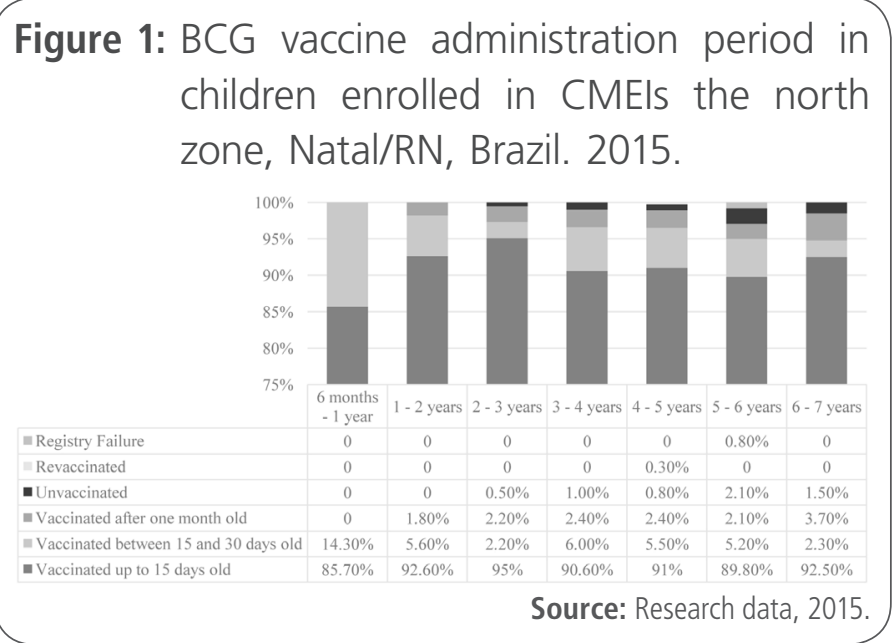

Table 1. Classification of the vaccination scheme of BCG vaccine in children enrolled in CMEls in the north zone, Natal/RN, Brazil. 2015.

\begin{tabular}{|c|c|c|c|c|c|c|c|c|}
\hline \multirow{3}{*}{\multicolumn{2}{|c|}{$\begin{array}{l}\text { Child's } \\
\text { age }\end{array}$}} & \multicolumn{4}{|c|}{ Complete Vaccination Scheme } & \multirow{3}{*}{ Unvaccinated } & \multirow{3}{*}{$\begin{array}{l}\text { Registry } \\
\text { Failure }\end{array}$} & \multirow{3}{*}{ Total } \\
\hline & & $\begin{array}{l}\text { Up to } 15 \text { days } \\
\text { old }\end{array}$ & $\begin{array}{c}\text { Between } 15 \\
\text { and } 30 \text { days old }\end{array}$ & $\begin{array}{l}\text { After one } \\
\text { month old }\end{array}$ & Revaccinated & & & \\
\hline & & \multicolumn{4}{|c|}{$n(\%)$} & & & \\
\hline $6 \mathrm{mor}$ & 1 year & $6(85.7)$ & $1(14.3$ & 0 & 0 & 0 & 0 & $7(100)$ \\
\hline \multirow{6}{*}{ years } & $1-2$ & $50(92.6)$ & $3(5.6$ & $1(1.8)$ & 0 & 0 & 0 & $54(100)$ \\
\hline & $2-3$ & $171(95)$ & $4(2.2)$ & $4(2.2)$ & 0 & $1(0.5)$ & 0 & $180(100)$ \\
\hline & $3-4$ & $272(90.6)$ & $18(6)$ & $7(2.4)$ & 0 & $3(1)$ & 0 & $300(100)$ \\
\hline & $4-5$ & $344(91)$ & $21(5.5)$ & $9(2.4)$ & $1(0.3)$ & $3(0.8)$ & 0 & $378(100)$ \\
\hline & $5-6$ & $343(89.8)$ & $20(5.2)$ & $8(2.1)$ & 0 & $8(2.1)$ & $3(0.8)$ & $382(100)$ \\
\hline & $6-7$ & $123(92.5)$ & $3(2.3)$ & $5(3.7)$ & 0 & $2(1.5)$ & 0 & $133(100)$ \\
\hline
\end{tabular}


Table 2. Classification of the vaccination scheme of the Hepatitis B vaccine in children enrolled in CMEls in the north zone, Natal/RN, Brazil. 2015.

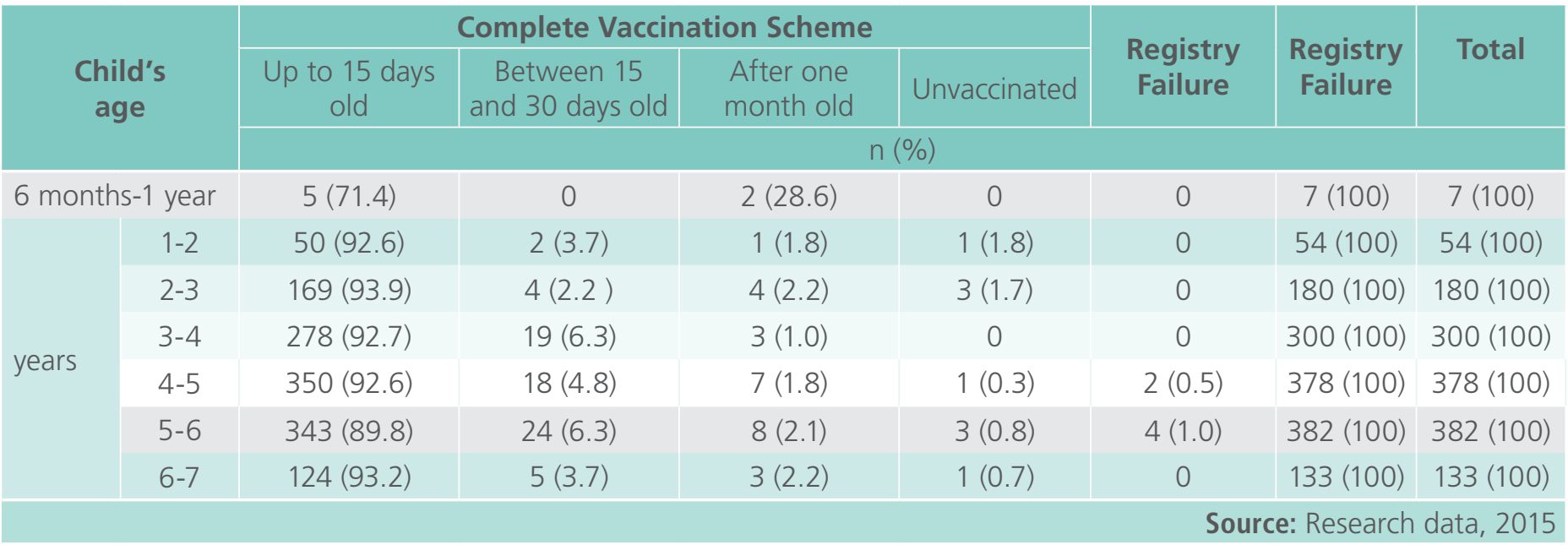

Figure 2: BCG vaccine administration period in children enrolled in CMEls the north zone, Natal/RN, Brazil. 2015.

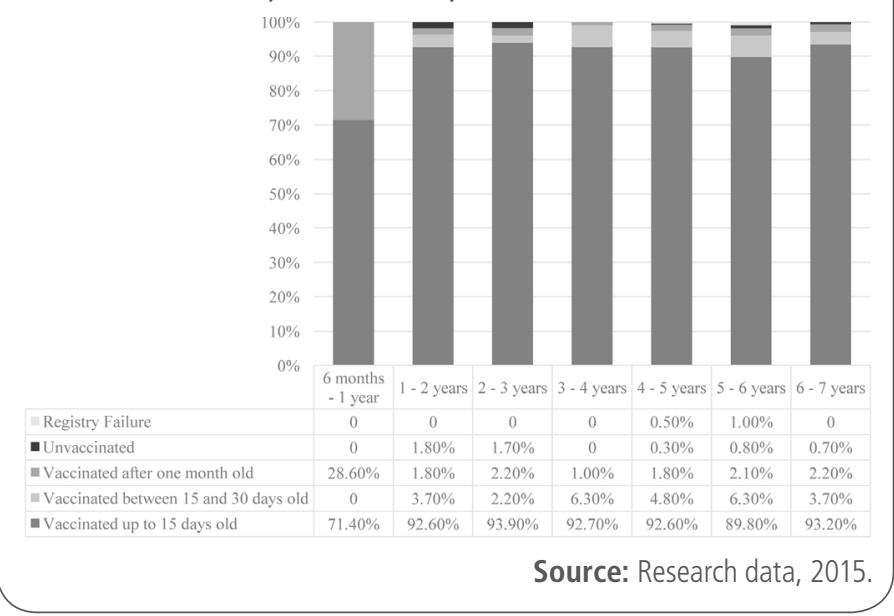

Table 2 presents the data regarding the first dose of the Hepatitis B vaccine. According to the data below, the classification of $98.9 \%$ of the cards was full vaccination scheme, in which $92 \%$ had the vaccine in the period recommended by the Ministry of Health (the first 15 days of life). The number of children who did not receive the first dose of Hepatitis B vaccine, and thus, had their cards classified as unvaccinated, was $0.6 \%$. There was registry failure of that vaccine in $0.4 \%$ of the cards, which prevented us from classifying the card.

Similarly to the BCG vaccine, it was possible to classify those cards considering the period of the vaccine administration. The number of children vaccinated against Hepatitis B in a moment well above that recommended by NIP - 30 days old - is even greater, especially in the last year. (Figure 2)

\section{Discussion}

Tuberculosis is an infectious disease, endemic in Brazil, which is a serious public health problem. The most effective measures to fight the disease are still the early detection and treatment of active tuberculosis patients. Another way to combat the disease is through vaccination. The vaccine used is BCG, whose administration should happen at birth, by a single intradermally dose [12].

Tuberculosis in childhood presents some peculiar characteristics: it is more aggressive than in adults, causing severe forms of the disease, with more extra pulmonary involvement and in disseminated forms. Vaccination with BCG produces an artificial primary infection, attenuated, caused by a non-virulent bacillus, which aims to increase natural resistance against later infection with a virulent bacillus. Studies on the BCG vaccine efficacy demonstrated greater protection for the most severe forms of the disease: tuberculous meningitis, miliary tuberculosis and disseminated forms. The pulmonary form of the disease in adolescents and adults did not have ade- 
quate protection when associated with vaccination. Vaccination protection rates for severe forms situate around $70 \%$. The earlier the vaccination, the greater the protection. Therefore, the estimation can reach $85 \%$ when administering the vaccine to newborns, $70 \%$, at 10 years old, and drops to $50 \%$ when this administration is over 20 years. The same studies also point out that the protection of the vaccine reduces gradually over time, especially after ten years of vaccination $[12,13]$.

The highest rates of mortality from the disease also occur in childhood. In the early 2000s, there was an estimated record of one million cases of tuberculosis in 0-14 years-old children, with two deaths of children in every minute, being the disease the highest number of deaths in developing countries. Tuberculosis in childhood represents 9.7\% of all diagnosed cases in Brazil [14]. However, we are still far from knowing the magnitude of that problem, since the diagnosis of the disease still presents limitations in the age group under six years, in addition to the strong association of symptoms to many other respiratory problems so common in childhood.

The NIP states, through the children's vaccination calendar, the administration of the dose to occur as early as possible, preferably within 12 hours after birth, in the maternity [6]. The contraindications of the vaccine is for individuals with a history of congenital or acquired immune deficiency; in the use of chemotherapy or corticosteroids in immunosuppressive dose; patients with burns or severe skin lesions, due to the risk of dissemination; pregnancy; and newborns weighing less than two kilos and acute febrile illness [6, 13].

Regarding Hepatitis B, global estimates suggest about two million people infected by the virus, with 350 million living with chronic infections and 600,000 deaths each year, either from acute or chronic causes [15].

Hepatitis B is a viral disease caused by hepatitis B virus, HBV, of the hepadnavirus family. Transmission occurs through contact with blood, during sexual intercourse, or perinatally. The virus migrates to the hepatocytes and, there, causes inflammation and necrosis, leading to chronic hepatitis. About $5 \%$ of patients infected by HBV become chronic carriers and there is record of a high hepatocellular carcinoma rate in those individuals. The chronic carrier state may occur more frequently in children, especially newborns, than in adults, and may relate to incompetent immune system. About $90 \%$ of infected newborns become chronic carriers, which result in a high risk of hepatocellular carcinoma [16].

Prevention of Hepatitis B occurs primarily through vaccination, but hyperimmune globulin can also be used. In places where there was widespread vaccination of children for hepatitis $B$, there was a significant decrease in the incidence of hepatocellular carcinoma in children. The vaccine is highly effective and has few side effects [16].

The Ministry of Health estimates that at least $15 \%$ of the population already had contact with the hepatitis B virus (HBV) at some point in their life. Chronic cases represent 1\% of the population, and the majority is unaware of their carrier status; however, this is an important agent in the disease's chain of transmission [17].

The analysis of data regarding the vaccination status of children for BCG and Hepatitis B showed us that, in northern Natal/RN, there was a vaccination coverage that surpasses the expectation proposed by the Ministry of Health for both vaccines. The National Immunization Program considers satisfactory a vaccination coverage above $90 \%$ in order to ensure adequate protection, and, in this study, the results point to levels higher than that in both analyzed vaccines.

Such results are also close to those revealed in a study on vaccination coverage of the basic scheme for the first year of life in capitals of the Brazilian Northeast [9]. In that work, the authors reached an average coverage for BCG in Natal of $95 \%$ in all socioeconomic strata, with a better coverage in 
stratum $E$, and the worst, in stratum A. However, with respect to Hepatitis $B$, the study reveals a low coverage that varies between $70 \%$ and $90 \%$, with the best results in strata $C$ and $D$, and the worst results in stratum $A$.

From the information, it is possible to see that most of the children attending the CMEls come from, considering the classification per strata proposed in the study of those authors, the strata D and $E$, representing those with the worst combination of salary and years of study, that is, the worst socioeconomic status (stratum E). The CMEls are public institutions generally located in peripheral areas of the city, but not exclusively, seeking to assist children in their first stage of education, which is the childhood education. Therefore, one mays suggest that those results are close to those obtained in other studies, which reveal a BCG coverage higher than the expected average of 95\%. Nevertheless, concerning Hepatitis $B$, it is necessary to consider that, although the results of this study has a "complete vaccination scheme" percentage above 95\%, it has limitations and cannot be compared in the same way, since this research only worked with the first dose of the vaccine, and not with the complete scheme proposed by the mentioned study, since, according to the child's vaccination schedule, the completion of this scheme relates to the administration of the pentavalent vaccine. Thus, that comparison is only possible if there had been an assessment of the association of the pentavalent vaccine or the individualized doses of hepatitis $B$ vaccine in situations with no pentavalent administration, which was not the purpose of this article. Thus, it was considered satisfactory the coverage of Hepatitis B when analyzing only the first vaccine dose; however, if there was an analysis of the whole scheme, there could have been values well below those found in this study. That fact draws attention because other researches have shown that, in vaccines that require multiple doses, vaccination coverage is always lower than others [18].
Observed a satisfactory number of children with complete vaccination scheme, it was also possible to see that, although they have taken a single dose of BCG and the first Hepatitis B dose, most of them, ranging between 2.1 and $14.3 \%$ for $B C G$ and 1 to $28.6 \%$ for hepatitis $B$, did it out of the period recommended by NIP. That may associate with structural problems and service offer.

In Natal, in the last two years, there has been a shortage regarding those vaccines that leads people to look for two or more services in an attempt to get them. Besides the lack of immunobiological, which has been recurrent, there is still the specificity of administration of BCG vaccine and the scarcity of professionals with the expertise to carry it out. Despite the high number of family health teams, not all units offer the BCG vaccine, mainly for lack of vaccinators trained for its administration. Such factors certainly should contribute to the delay in the child's first vaccines.

Another fact that draws our attention is the presence of the vaccine registry errors. Such errors prevented the analysis and classification of the child's card. They related mainly to the date of the vaccine administration. Despite existing, in the child's card, the space marked for each vaccine, there still are current cards that have different records. The name of the vaccine and the date, in addition to information on batch, place of administration and guardian are essential and mandatory information for that procedure. Without them, there is a risk of subsequent doses without respecting the required timeout period for each immunobiological, which can lead to undesirable side effects: there may be administration of wrong vaccine, in wrong times and at the wrong age. Such errors are unacceptable and threaten children's safety, even putting their lives at risk.

Considering the advances in the quality of care and health services to the population, patient safety is a major concern, and, within it, there is the importance of records in medication administration. 
Regarding immunobiologicals, the concern should be the same. Although considered organic products safe for human use, considering all quality procedures they go through for their production, conservation and management, they are not free from causing side effects, whether expected or not. In this sense, the monitoring of post-vaccination adverse events must remain so that risks do not exceed the benefits achieved by vaccination [19]. Nevertheless, despite the understanding and realization that mistakes are common in the record of the applied doses of vaccine, either in the room maps, mirror cards or child's card, in the documents of the Ministry of Health, it is possible to verify the concern to record the vaccine so that there are no erroneous data to the information system, but they do not clarify the consequences to children's health [6].

On the other hand, the absence of the child's clinical condition associated with possible side effects of vaccination at the time health professionals treat that child also contributes to the lack of reliable data that can help assess the real dimension of the problem.

\section{Conclusions}

The first dose of the Hepatitis B and BCG vaccines to children in CMEls in northern Natal have full vaccination schedule rates higher than the target set by the NIP, reaching $98-99 \%$ of the analyzed cards. That shows a coverage that can guarantee the protection of the child population against the main events arising from those two infectious diseases.

On the other hand, although children take the vaccine, some have done it later than recommended, which may associate with the lack of immunobiological in the service network, as well as trained professionals in the administration of BCG vaccine in the municipality of Natal. In this regard, there should be efforts to increase the number of vaccine rooms in the city, with skilled professional.
It is necessary to consider the registry errors that have been occurring in vaccination cards. Training on immunization, on patient safety, is essential in this regard; however, it is also necessary the epidemiological surveillance to give emphasis to the consequences regarding the presence of side events to the child's health.

\section{References}

1. Unicef. Fundo Das Nações Unidas Para A Infância. Situação Mundial Da Infância 2008: Sobrevivência Infantil. Brasília: Fundo Das Nações Unidas Para A Infância; 2007. Available from: http://www.unicef.org/brazil/pt/sowc2008 br.pdf

2. OMS. Organización Mundial De La Salud; Fondo De Las Naciones Unidas Para La Infancia; Banco Mundial. Vacunas E Inmunización: Situación Mundial. Geneva: Organización Mundial De La Salud; 2010. Available from: http://apps.who.int/ iris/bitstream/10665/44210/1/9789243563862 spa.pdf

3. Hochman, G. Vacinação, varíola e uma cultura da imunização no Brasil. Rev. Ciênc. saúde coletiva (Rio J.). 2011; 16(2): 375-86. Available from: http://www.scielo.br/pdf/csc/v16n2/v16n2a02.pdf

4. Ministério da Saúde. Programa Nacional de Imunizações 40 anos. Secretaria de Vigilância em Saúde. Departamento de Vigilância das Doenças Transmissíveis. Brasília: MS, 2013. Available from: http://bvsms.saude.gov.br/bvs/publicacoes/ programa nacional imunizacoes pni40.pdf

5. Ministério da Saúde. Programa Nacional de Imunizações - 30 anos. Brasília: Ministério da Saúde: Secretaria de Vigilância em Saúde; 2003. Available from: http://bvsms.saude.gov.br/bvs/ publicacoes/livro 30 anos pni.pdf

6. Ministério da Saúde. Secretaria de Vigilância em Saúde. Departamento de Vigilância das Doenças Transmissíveis. Manual de Normas e Procedimentos para Vacinação. Brasília: Ministério da Saúde; 2014. Available from: http://bvsms.saude.gov.br/bvs/ publicacoes/manual procedimentos vacinacao.pdf

7. Pereira MG. Epidemiologia: Teoria e Prática. 1.ed. Rio de Janeiro: Guanabara Koogan; 2013.

8. Oliveira MFS, Martinez EZ, Rocha JSY. Fatores associados à cobertura vacinal em menores de cinco anos em Angola. Rev Saúde Pública. 2014; 48(6):906-15. Available from: http://www. scielo.br/pdf/rsp/v48n6/pt_0034-8910-rsp-48-6-0906.pdf

9. Queiroz LLC, Monteiro SG, Mochel EG, Veras MASM, Sousa FGM, Bezerra MLM. et al. Cobertura vacinal do esquema básico para o primeiro ano de vida nas capitais do Nordeste brasileiro. Cad. Saúde Pública (Rio J.). 2013; 29(2):294-302. Available from: http://www.scielo.br/pdf/csp/v29n2/16.pdf 
10. Araújo TME, Sá LC, Silva AAS, Costa JP. Cobertura vacinal e fatores relacionados à vacinação dos adolescentes residentes na área norte de Teresina/PI. Rev Eletrônica Enferm. 2010; 12(3):502-10. Available from: https://www.fen.ufg.br/fen revista/v12/n3/pdf/v12n3a13.pdf

11. Moraes JC, Ribeiro MCSA. Desigualdades sociais e cobertura vacinal: uso de inquéritos domiciliares. Rev Bras Epidemio. 2008; 11(supl 1): 113-24. Available from: http://www.scielo.br/pdf/ rbepid/v11s1/10.pdf

12. Succi RCM. Vacina BCG. In: Sato HK, Sáfadi MAP, Kfouri RA, Marques SR. Imunizações em Pediatria. 1.ed. São Paulo: Atheneu; 2013.25

13. Gilio AE. (coord). Manual de imunizações: centro de imunizações Hospital Israelita Albert Einstein. 4.ed. Rio J: Elsevier; 2009.

14. Zombini EV, Almeida CHD, Yamada ES, Komatsu NK, Figueiredo SM. Clinical epidemiological profile of tuberculosis in childhood and adolescence. Rev. bras. crescimento desenvolv. hum. [online]. 2013; 23(1): 52-57. Available from: http://pepsic. bvsalud.org/pdf/rbcdh/v23n1/pt 08.pdf

15. Secretaria do Estado da Saúde. Coordenadoria de Controle de Doenças. Centro de Vigilância Epidemiológica. Informe Técnico Hepatite Viral B. São Paulo: Governo do Estado de São Paulo; 2016. Available from: ftp://ftp.cve.saude.sp.gov.br/doc_tec/ hepa/doc/IF11 HBV.pdf

16. Levinson W. Microbiologia Médica e Imunologia. 10.ed. Porto Alegre: Artmed; 2010.

17. Bueno MM, Matijasevich A. Avaliação da cobertura vacinal contra hepatite $B$ nos menores de 20 anos em municípios do Estado do Rio Grande do Sul, Brasil 2011. Epidemiol. Serv. Saúde. 2011; 20(3):345-54.

18. Yokokura AVCP, Silva AAM, Bernardes ACF, Filho FL, Alves MTSSB, Cabra NAL. Cobertura vacinal e fatores associados ao esquema vacinal básico incompleto aos 12 meses de idade, São Luís, Maranhão, Brasil, 2006. Cad. Saúde Pública. 2013; 29(3):522-34. Available from: http://www.scielo.br/pdf/csp/ v29n3/a10v29n3.pdf

19. Ministério da Saúde. Secretaria de Vigilância em Saúde. Departamento de Vigilância Epidemiológica. Manual de vigilância epidemiológica de eventos adversos pós-vacinação. Brasília: Ministério da Saúde; 2014. Available from: http://www. saude.pr.gov.br/arquivos/File/-01VACINA/manual Eventos adversos.pdf
Publish in International Archives of Medicine

International Archives of Medicine is an open access journal publishing articles encompassing all aspects of medical science and clinical practice. IAM is considered a megajournal with independent sections on all areas of medicine. IAM is a really international journal with authors and board members from all around the world. The journal is widely indexed and classified Q2 in category Medicine. 